\title{
Integrating Indigenous and Scientific Knowledge for Decision Making of Rice Farming in South Sulawesi, Indonesia
}

\author{
Syahrul Yasin Limpo ${ }^{1}$, Imam Mujahidin Fahmid ${ }^{2}$, Abdul Fattah ${ }^{3}$, Abdul Wahid Rauf ${ }^{3}$, Elza Surmaini ${ }^{4, *}$, \\ Muslimin ${ }^{5}$, Saptana ${ }^{6}$, Haris Syahbuddin ${ }^{7}$ and Kuntoro Boga Andri ${ }^{8}$
}

check for

Citation: Limpo, S.Y.; Fahmid, I.M.; Fattah, A.; Rauf, A.W.; Surmaini, E.; Muslimin; Saptana; Syahbuddin, H.; Andri, K.B. Integrating Indigenous and Scientific Knowledge for Decision Making of Rice Farming in South Sulawesi, Indonesia. Sustainability 2022, 14, 2952 https://doi.org/10.3390/su14052952 Academic Editor: Jun-Ichi Sakagami Received: 13 December 2021 Accepted: 25 February 2022 Published: 3 March 2022

Publisher's Note: MDPI stays neutral with regard to jurisdictional claims in published maps and institutional affiliations.

Copyright: (c) 2022 by the authors Licensee MDPI, Basel, Switzerland. This article is an open access article distributed under the terms and conditions of the Creative Commons Attribution (CC BY) license (https:// creativecommons.org/licenses/by/ $4.0 /)$.
1 Ministry of Agriculture, Jl. Harsono RM No.3, Ragunan, Pasar Minggu, Jakarta Selatan 12550, Indonesia; syahrul.yasinlimpo@pertanian.go.id

2 Department of Socio-Economics, Faculty of Agriculture, Hasanuddin University, Jl. Perintis Kemerdekaan Tamalanrea, Kota Makassar 90245, Indonesia; imam.m.fahmid@gmail.com

3 Assessment Institute for Agricultural Technology of South Sulawesi, The Indonesian Agency for Agricultural Research and Development, Ministry of Agriculture, Jl. Perintis Kemerdekaan Km. 17, 5, Kota Makassar 90242, Indonesia; abdulfattah911@ymail.com (A.F.); awrauf2010@yahoo.com (A.W.R.)

4 Indonesian Agro-Climate and Hydrology Research Institute, The Indonesian Agency for Agricultural Research and Development, Ministry of Agriculture, Jl. Tentara Pelajar 1A, Bogor 16111, Indonesia

5 Indonesian Cereals Research Institute, The Indonesian Agency for Agricultural Research and Development, Ministry of Agriculture, Jl. DR. Ratulangi No.274, Maros 90512, Indonesia; muspaowe@yahoo.com

6 Indonesian Center for Agricultural Socio Economics and Policy Studies, Ministry of Agriculture, Jl. Tentara Pelajar No.3, Bogor 16124, Indonesia; saptana.07@gmail.com

7 Indonesian Agency for Agricultural Research and Development, Ministry of Agriculture, Jl. Ragunan 29 Pasar Minggu, Jakarta Selatan 12540, Indonesia; harissyahbuddin@yahoo.com

8 Public Relations and Information Bureau, Ministry of Agriculture, Jl. Harsono RM No.3, Ragunan, Pasar Minggu, Jakarta Selatan, Jakarta 12550, Indonesia; kuntoro@pertanian.go.id

* Correspondence: elza@pertanian.go.id or elzasurmaini@gmail.com

\begin{abstract}
Agricultural activities cannot be separated from indigenous knowledge (IK), which has developed and continues to be strongly maintained by Bugis-Makassar farmers in the face of rapidly developing science and technology. The objective of this study was to explore the IK practices in rice cultivation of the Bugis-Makassar farmer community, as well as the process of integrating IK and scientific knowledge into decision making. The study used a number of qualitative methodologies to gather information, including meetings, focus group discussions, in-depth interviews, and semistructured interviews. Our results show that IK is slowly disappearing and being replaced by middle-aged people and youth, who seem to care more about modernization than assimilation. However, with the existence of Tudang Sipulung, the fading of local wisdom may be inhibited. Tudang Sipulung's strength lies in the government's involvement in integrating IK and scientific knowledge into formal forums and agreement. The Tudang Sipulung agreement is formally binding with constitutional sanctions applied. In order to provide optimum benefits, engaging young farmers in the understanding and preservation of indigenous and scientific knowledge is recommended to preserve local culture and transfer modern technology.
\end{abstract}

Keywords: Tudang Sipulung; indigenous knowledge; decision making; scientific; rice farming; planting time

\section{Introduction}

Indonesia is rich in indigenous and local knowledge transmitted from generation to generation. Forms of IK may take the form of special systems of values, norms, beliefs, and rules related to human activities in a society. Certain forms of IK also play a role in the management of natural resources and the environment to maintain a balance between nature and its sustainability [1,2]. One example is the IK which grows and develops through agriculture and plays an important role in achieving food security [3,4]. Some examples of 
forms of IK in local agricultural practices that can be found are Subak (traditional irrigation system) in Bali, Nyabuk Gunung (contour planting) on the slopes of Sindoro and Sumbing mountains, Central Java, Pranoto Mongso (season determination) and Bondang (organic farming) in Asahan, North Sumatra, and Tudang Sipulung (determination of planting season) in South Sulawesi.

Agricultural development cannot be dissociated from the IK that still belongs firmly to the agricultural community of South Sulawesi, because the IK is carried and rooted across generations. IK goes beyond what is reflected in farming methods and techniques, but it also includes environmental knowledge, perception, and consciousness or intuition, and it frequently involves calculating the motion of the moon or the sun, astrology, environmental conditions, geology, and meteorology. According to Syahruna [5], agriculture-related culture refers to all activities with particular characteristics, including the sound management of agricultural land, the rituals that are still practiced, the equipment used, and even all activities directly related to the activities of planting, maintaining, and harvesting agricultural products.

IK is interpreted as local or traditional knowledge that indigenous peoples brought with them from earlier times through oral tradition. IK is also referred to as cultural identity, i.e., the identity or cultural personality of the nation [6]. This enables the nation to absorb and deal with foreign cultures in terms of character and ability. IK is the true knowledge of a population that reflects traditions and experiences, including new experiences of modern agriculture technology [7-9]. Local communities, including farmers, agricultural workers, women, and artisans in rural areas are the custodians of the local knowledge system.

The province of South Sulawesi is one of the largest food-producing regions, particularly rice, in East Indonesia. With a production of 4.708 million tons in 2020, it is the largest rice producer outside Java, which contributes the most to rice production in Indonesia. According to an inter-census agricultural survey (2019) [10], there are 1,015,232 farm families (farm households) in the province of South Sulawesi, $87 \%$ of which are food crop producers. Of these, only $11.2 \%$ are young farmers under the age of 35 , indicative of the aging of farmers in the south of Sulawesi.

There are four major tribes living in South Sulawesi; Bugis (41.9\%), Makassar (25.43\%), Toraja (9.02\%), and Mandar (6.01\%), with Bugis and Makassar being the majority, accounting for up to $67.33 \%$ [11]. Although they are of different ethnic origins, Bugis and Makassar have similarities in rice farming practices that are still significantly informed by their experiences of personal physical observation of the environment. For example, local populations have developed personal weather forecasting techniques involving careful observation of star shapes in the sky, and they have traditional practices in the rice farming system. Furthermore, Bugis and Makassar have some common features of the agricultural tradition prior to seed planting and after the harvest called Tudang Sipulung. Tudang Sipulung is a local wisdom practiced by farmers to solve problems related to agriculture, geared toward meeting the needs of local communities and being more sustainable and integrated into governmental and educational activities [12-15]. In Tudang Sipulung, farmers discuss the appropriate planting schedule, selection of the paddy variety, use of artificial fertilizers, and agreement on the price of the paddy [16]. A later development showed that Tudang Sipulung is not just a cultural ritual, but also a method or strategy used to solve problems in the community [17].

Faced with climate change and its emerging challenges, there is a growing awareness that formal scientific knowledge alone is inadequate to solve the climate crisis $[18,19]$. In recent years, IK is increasingly being recognized as an important source of climate knowledge and adaptation strategies. It is essential that decision making for policies and actions are based upon the best available knowledge. In this case study, we investigate how the indigenous peoples of the Bugis-Makassar tribe and the scientists created a constructive dialogue in Tudang Sipulung, reaching an agreement for decision making of rice farming practices for the following season. The purpose of this study was to explore 
the IK practices in rice farming of the Bugis-Makassar farmer community, as well as the process of integrating IK and scientific knowledge into rice farming decision making.

\section{Literature Review}

Since the 1970s, there has been a growing body of literature highlighting the importance of integrating local knowledge and practices in the development of IK from generation to generation. According to Warren (1993) [20], IK is the systematic body of knowledge acquired by local people through the accumulation of experiences, informal experiments, and an intimate understanding of the environment in a given culture. IK includes accumulated knowledge, as well as the skills and technologies of local people that are developed locally and passed down through the centuries [21]. Chisenga (2002) [22] identified some characteristics of IK. It is generated within specific communities, places, and cultures, and it has been transformed by local people and incorporated into their way of life. It is not systematically documented, but dynamic, grounded in innovation, adaptation, and experimentation, and oral and rural in nature. It is also based on experience, tested over the centuries, adapted to the local culture and environment, and expressed in local languages.

One area that has effectively utilized IK is agriculture. In subsistence agriculture, IK has been used throughout the production value chain. For centuries, farmers have been planning agricultural production and preserving natural resources using IK tools $[19,23,24]$. The indigenous agricultural system is participatory and allows farmers to interact with their environment through their ingenuity, experiences, and available local resources that have built up over time. The IK plays a major role in agriculture through various means such as climate change forecasting, prediction of rainfall, crop selection [25-27], and adjusting planting calendars, drought tolerant varieties, and irrigation practices [28-30].

IK in determining planting time has long been the practice of farmers around the world. Farmers generally used their knowledge with a combination of plant phenology, animal behaviors, and the appearance and shape of the moon and stars to predict rainfall characteristics and adjust the planting season, such as in Tanzania Uganda [26,31], South Africa [32], Vietnam [29], Ghana [33], Ethiopia [24], Zambia [25], and the Philippines [34]. The farmers of Padaviya Srilangka determine the appropriate time to plant rice according to the rainfall pattern and the lunar calendar [35]. The rice farmers of Barangai Biga, Philippines, consult the Tagalog Calendar of Honorio Lopez when deciding on different farming activities, particularly fortunate days for ploughing, planting, and harvesting [34].

Both IK and scientific knowledge share similar characteristics. Observation is an important method for indigenous and scientific knowledge. In scientific knowledge, observation is a vital part of scientific data. Scientists interpret and analyze the data to substantiate or refute their hypotheses and theories. In the case of IK, knowledge can be acquired through repeated observations. Waithaka (2021) [36] summarizes the characteristics of IK and scientific knowledge from various authors, as shown in Table 1.

The application of IK has led to productive, ecologically sound, and sustainable agriculture. IK contains an abundance of ecological wisdom, which could provide solutions to environmental problems related to agriculture, whereas scientific knowledge plays an important role in improving agricultural productivity and farmer income from an economic perspective [37]. However, formal education and technology drive indigenous smallholder farmers away from traditional agricultural practices, leading to the loss of much of this knowledge. At the same time, the international community calls for the inclusion of IK as a path to sustainable agriculture for smallholder farmers [38]. 
Table 1. The different characteristics of IK and scientific knowledge.

\begin{tabular}{|c|c|}
\hline IK & Scientific Knowledge \\
\hline Locally generated by farmers on their farms & $\begin{array}{l}\text { Generated by researchers in research } \\
\text { institutions }\end{array}$ \\
\hline $\begin{array}{c}\text { Based on farmers' years of experience, practice, } \\
\text { and testing }\end{array}$ & $\begin{array}{c}\text { Based on years of scientific experimentation } \\
\text { and adaptation trials }\end{array}$ \\
\hline $\begin{array}{l}\text { Context-specific; different rural communities } \\
\text { have their own knowledge }\end{array}$ & $\begin{array}{l}\text { Context-specific; different agroecological zones } \\
\text { (AEZs) have their own recommendations }\end{array}$ \\
\hline $\begin{array}{l}\text { Based on principles that may be } \\
\text { community-specific since they are influenced } \\
\text { by local materials and culture }\end{array}$ & $\begin{array}{c}\text { Based on general principles formulated for } \\
\text { AEZs, which may cut across different } \\
\text { communities }\end{array}$ \\
\hline $\begin{array}{l}\text { Emphasizes survival and settles for low } \\
\text { production in return for sustainability in the } \\
\text { long term }\end{array}$ & $\begin{array}{l}\text { Emphasizes risk taking for maximum } \\
\text { production and profit in the short term }\end{array}$ \\
\hline $\begin{array}{l}\text { Requires high labor, depends on local inputs, } \\
\text { and emphasizes diversity }\end{array}$ & $\begin{array}{c}\text { Requires low labor, is highly dependent } \\
\text { onexternal inputs, and emphasizes } \\
\text { monoculture }\end{array}$ \\
\hline $\begin{array}{l}\text { It is implicit knowledge expressed through } \\
\text { values and actions and is orally transmitted }\end{array}$ & $\begin{array}{l}\text { Explicit knowledge is easily expressed in } \\
\text { words and is often documented }\end{array}$ \\
\hline
\end{tabular}

Farmers are the principal actors of agricultural development. However, in the agricultural extension system, farmers have no voice, particularly with respect to IK and what they need from the experts. No upward feedback mechanism exists; farmers are treated as passive recipients, and their voices are widely ignored [37]. In mainstream agricultural policies in Africa, for instance, local knowledge is often considered as an issue [39], and the solution is to modernize agriculture by harnessing modern science and technology to improve crop yields [40,41]. According to Mellor (2017) [42], "farmers may well innovate but innovation is generated locally from local practices and is innately slower-paced than that from modern research institutions. It is not embodied in purchased inputs."

In order to engage IK productively in development, Agrawal (1995) [43] argued that the dichotomy between indigenous and scientific knowledge and work must be overcome, and efforts must be made to bridge the gap between the indigenous and scientific divide. This requires parity and integration of the traditional and scientific knowledge system. In an attempt to address these challenges, participatory techniques are used to integrate IK and science into disaster risk reduction. It is expected that this will be a useful tool for identifying how the two sets of knowledge can be successfully integrated [44]. Furthermore, according to Mistry and Berardi (2016) [45], any effort to solve a problem should engage the local communities most affected, using the IK approach and seeking relevant scientific knowledge, not to validate IK, but to broaden the range of options. The integration of indigenous and scientific knowledge can, therefore, balance the economic and ecological dimensions of sustainable agriculture. In terms of integrating IK with scientific knowledge, more in-depth and participatory field research is needed to deepen the integrated understanding and interpretation of the respective roles of science and IK by researchers [37].

\section{Methods}

This study used specific qualitative methodologies to gather information, as described by [30]. Information was collected through meetings at a provincial level $(n=8)$, focus group discussions $(n=8)$, in-depth interviews with key persons in the agricultural community $(n=4)$, semi-structured interviews with farmer respondents $(n=36)$ (Table 2$)$, and identification of the planting time according to the Integrated Cropping Calendar Information System (ICCIS). In addition to the aforementioned research method, we gathered further information augmented by the insights, assumptions, and experiences of scientists, farm group leaders, published and unpublished literatures, and other sources of information. The total data collection is summarized in Figure 1. 
Table 2. Description of data collection.

\begin{tabular}{ccc}
\hline No & Methods & Number of Participants \\
\hline 1 & Meetings & 8 \\
2 & Focus group discussions & 8 \\
3 & In-depth interviews & 16 \\
4 & Semi-structured interviews & 36 \\
5 & Identification of planting time according to ICCIS & \\
\hline
\end{tabular}

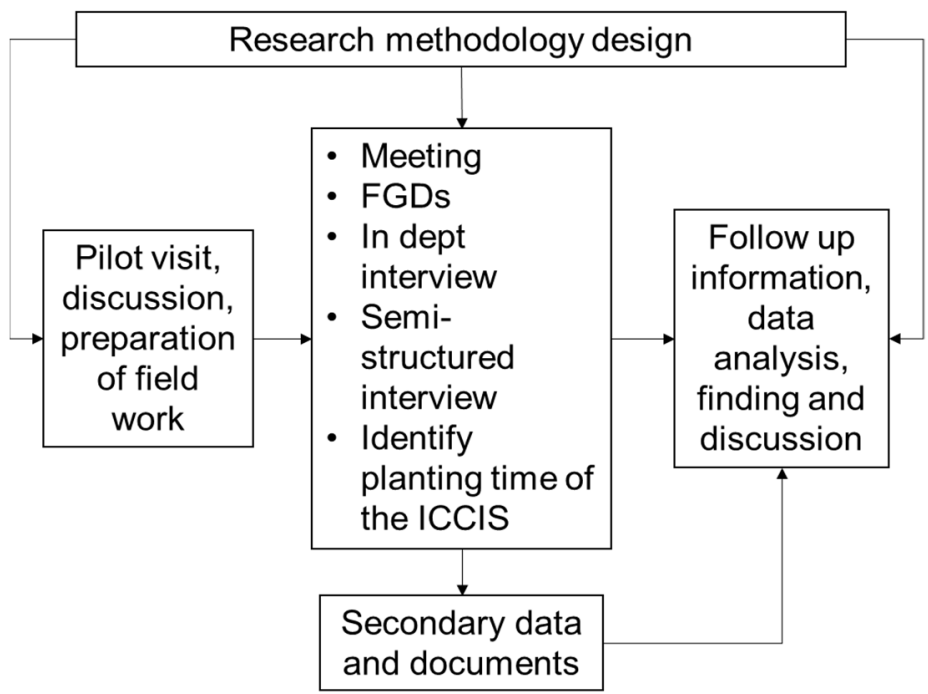

Figure 1. Flowchart of data collection and analysis.

\subsection{Limitation}

First, this study involved some farmers for further in-depth analysis. However, the selected key persons had extensive knowledge and experience on IK, which arguably provided further insights. Secondly, the research was limited to 4 months for the same reasons. Consequently, the empirical findings of this study may not be generally applicable.

\subsection{Pilot Visit and Preparation Work}

A pilot visit was held in December 2020 for meetings with research institutions and agricultural offices to obtain an overview of IK practices in the rice farming system and to determine study sites. Secondary data, including various annual reports by the offices for agricultural statistics and the agricultural office, as well as monthly rainfall data, were also collected as part of the visit. This empirical information subsequently enabled us to formulate research ideas, which were also recorded during this visit.

\subsection{Meeting}

A meeting was organized with eight key local participants from the area. This group comprised the following members: three from the Agricultural Technology Assessment Center (BPTP), two representatives of the Farmers' Union, and three from the Agricultural Extension Office. The main questions were used to uncover extensive topics related to IK in rice cultivation and detailed information about Tudang Sipulung. During this meeting, four study subdistrict sites were selected for three main reasons: (1) the local livelihoods are largely dependent on rice cultivation; (2) they represent the local culture or the wisdom of the Bugis-Makassar people; (3) most residents have a long history of applying local rice growing practices.

Four subdistricts were selected on the basis of the recommendations of the meeting participants. These subdistricts included the Takkalalla Subdistrict (Wajo District), Panca Lautang Subdistrict (Sidrap District), Tellu Settiannggeng Subdistrict (Bone District), and Galessong Subdistrict (Takalar District), South Sulawesi Province (Figure 2). The Wajo, 
Sidrap, and Bone Districts represent the local culture or the wisdom of the Bugis tribe, whereas the Takalar District represents the Makassar tribe.

\section{SOUTH SULAWESI PROVINCE}

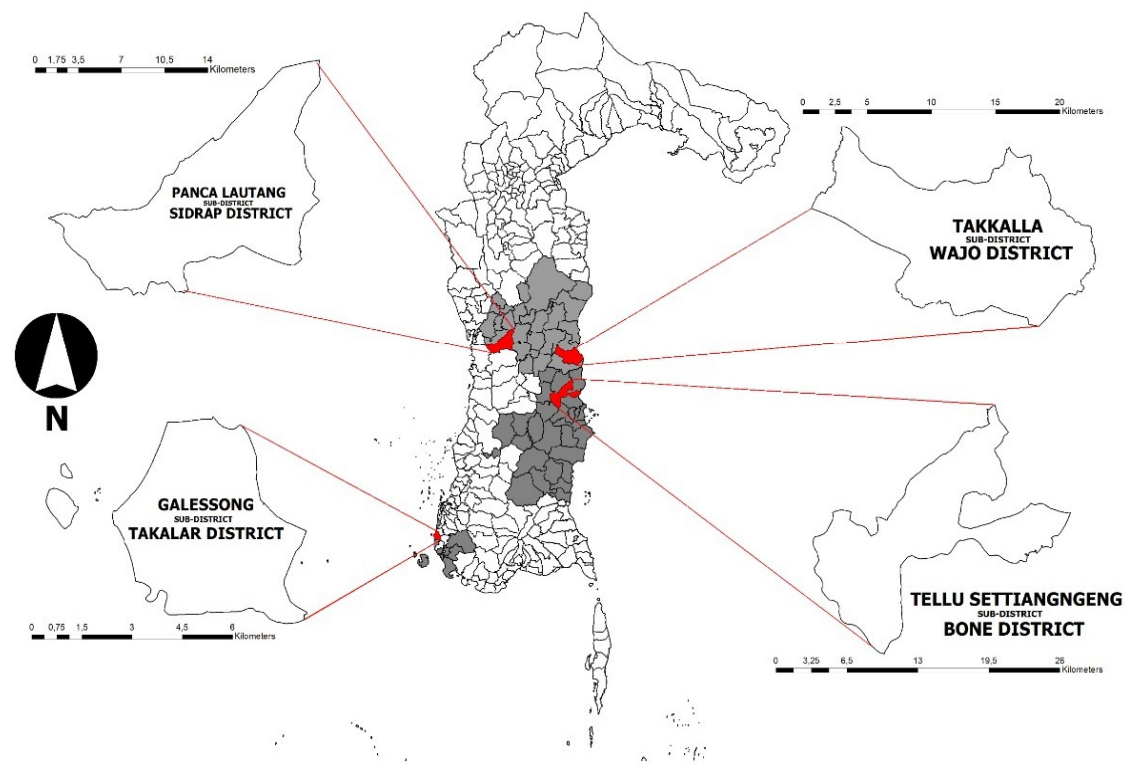

Figure 2. Map of South Sulawesi Province (red dot indicates study sites).

\subsection{Focus Group Discussion (FGD)}

In this study, FGDs were organized to acquire information, cross-check information, and clarify information collected by previous sources (pilot trips, meeting, and secondary data). The FGDs focused on accurately determining the precise farmers' activities and how they applied their IK in rice farming practices. The FGDs also mapped detailed activities in Tudang Sipulung, indicating how and when they were implemented, as well as the actors involved. FGD was conducted with eight key informants aged 40 to 60 . The participants were knowledgeable individuals with long-term farming experiences such as community leaders, farm leaders, agricultural officers, and representatives of the Farmers' Union. Therefore, when they were questioned on issues related to their strengths, they felt comfortable sharing them. Furthermore, during these processes, the facilitator used the voting system to unify information across groups to ensure the accuracy of the information.

\subsection{In-Depth Interview}

A total of 16 participants were selected for in-depth interviews, four participants from each subdistrict. In-depth interviews were conducted with key informants, namely, the Pallontara and Pappananrang, who are knowledgeable in the local wisdom of rainfall prediction, planting time adjustment, and likelihood of occurrence of pests and diseases, which represent the key information discussed in Tudang Sipulung. Interviews were also conducted with community and farm leaders, extension workers, and agricultural officers at each location to gather information on Tudang Sipulung at the district level. The information collected concerned the resource person at Tudang Sipulung, topics discussed in Tudang Sipulung, the mechanism or process to determine the agreement, and case studies on the recommended planting time in Tudang Sipulung in 2018-2021 for subdistrict levels, sanctions, and institutions.

\subsection{Semi-Structured Interview}

Following the collection and classification of information and data through the indepth interviews, a semi-structured questionnaire was designed for interviews with farmer respondents. Interviews were conducted with 36 individuals representing the 
Bugis-Makassar people with three farmer age classifications: young ( $<35$ years), adult (35-55 years), and senior ( $>55$ years). The age criteria may have elements of subjectivity because the selection of respondents by age depended on the researcher. The selection of respondents was based on stratified purposive sampling to collect information on local knowledge of farming practices, including soil treatment, seeding and timing of planting, maintenance, pest and disease control, and harvest and post-harvest activities. In addition to close-ended questions, the study included some open-ended questions to enable interviewees to explain their responses in more detail, especially those related to local rice farming practices.

\subsection{Comparison of IK and Scientific Knowledge in Adjusting Rice Planting Time}

For comparison purposes, planting time according to the scientific knowledge of the ICCIS was considered. The ICCIS provides recommendations on planting time, cropping pattern, planting area, varieties, fertilizers, farm machinery, potential food, and crop damage due to extreme conditions for rice, maize, and soybeans, for the upcoming planting season. The ICCIS analyzed the planting time and seeded area for all Indonesian regions using water balance calculations and precipitation forecasts for the next 6 months [46]. The ICCIS is accessible at https:/ / katam.litbang.pertanian.go.id/ (accessed on 2 December 2021).

\section{Results and Discussion}

\subsection{Use of IK in Rice Farming Practices of Bugis and Makassar Tribe}

The traditions, rules, and customs of the Bugis-Makassar farming communities in rice cultivation represent the local wisdom which continues to develop and is still used today, even though it has been weakened by developments in science and technology. According to the in-depth interviews with key informants, technical rice cultivation practices are presented in Figure 3. These include preparing land and seed, adjusting planting time, planting, controlling pests and diseases, maintaining plants, and harvesting, which are rich in local knowledge. Table 2 provides a description of IK in rice farming practices.

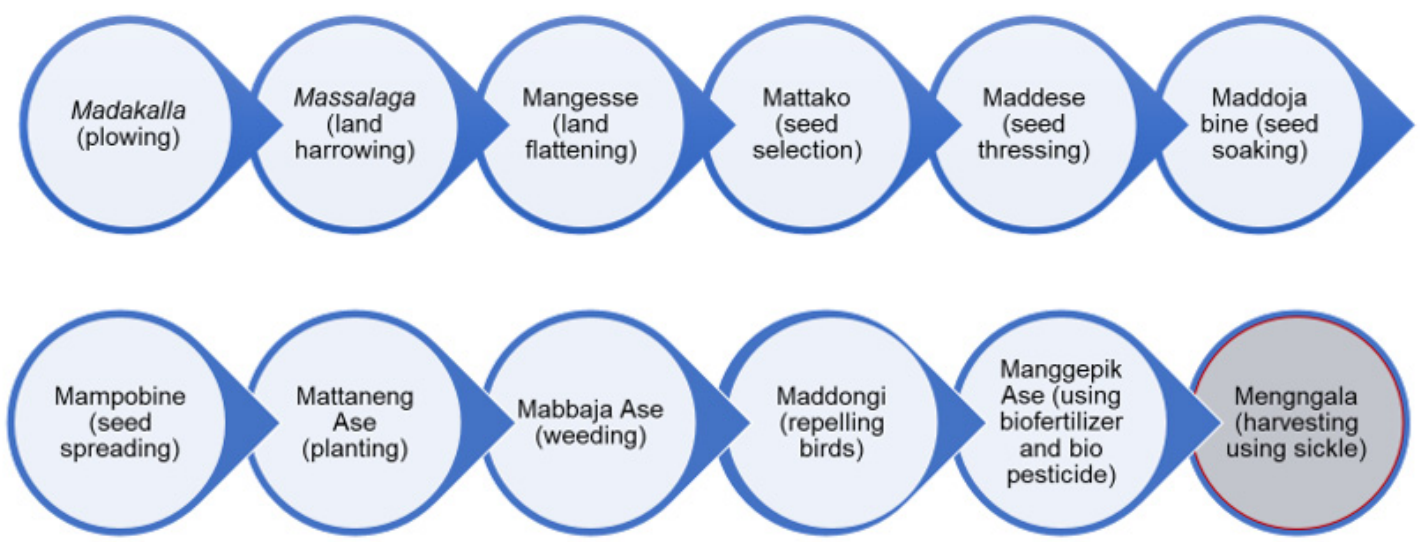

Figure 3. Local knowledge in rice farming practices of the Bugis-Makassar tribe.

On the basis of the interview, it can be assumed that most of the IK in rice farming described in Table 3 is autonomously implemented by smallholder farmers without support from the other sources outside the community such as local authorities or government organizations. Therefore, indigenous farming methods should be incorporated into the current governmental policies. This will enable these groups to maintain themselves in a more sustainable manner, as well as to effectively adapt to the problems of low production. However, it is important not to lose the IK of agricultural practices that has been maintained throughout generations, due to modern agricultural technology and socioeconomic conditions [29]. 
Table 3. Description of the IK in rice farming practices of the Bugis-Makassar tribe.

\begin{tabular}{|c|c|c|}
\hline No & IK Practices & Description \\
\hline 1 & Madakalla & $\begin{array}{l}\text { A first-stage tilling method that aims to overturn and loosen the soil to a depth of } 30 \text { to } 45 \mathrm{~cm} \text { using } \\
\text { Rakkala which is hauled by cows and buffaloes. Rakkala is a kind of plough made of iron and solid wood } \\
\text { like the trunks of tamarin trees, sandalwood trees, and other types of trees. }\end{array}$ \\
\hline 2 & Massalaga & $\begin{array}{l}\text { The second stage of tillage, which aims to destroy pieces of soil using the Salaga, a kind of rake shaped } \\
\text { like a wooden comb. This tool is designed to break the soil and pulled by two cows or two buffaloes. }\end{array}$ \\
\hline 3 & Mangesse & $\begin{array}{l}\text { The third tillage designed to level the soil using flat, thin wood pulled by two cows or two buffaloes. A } \\
\text { loose and level soil is ready to be planted. }\end{array}$ \\
\hline 4 & Mattako Bine & $\begin{array}{c}\text { Seed preparation, whereby rice panicles that are uniform in appearance, pithy, and not attacked by pests } \\
\text { and diseases are selected and converted into quality rice seeds. }\end{array}$ \\
\hline 5 & Maddesse & $\begin{array}{c}\text { Separation of panicles from rice seeds by trampling panicles barefoot to prevent the appearance of } \\
\text { damaged rice seeds. This is done because the rice seeds used are typically local rice with panicles that } \\
\text { are hard to beat. }\end{array}$ \\
\hline 6 & Maddoja Bine & $\begin{array}{l}\text { Soaking of the rice seeds in water for } 2 \text { days to accelerate the germination process. Once the embryo is } \\
\text { extracted, it is immediately dried and ready for planting. All these seed treatment processes begin with } \\
\text { special rituals as a form of seed appreciation, which mark the beginning of the pursuit of a life. }\end{array}$ \\
\hline 7 & Mampo Bine & $\begin{array}{c}\text { The activity of dispersing rice seeds by hand by experienced traditional elders to ensure that seeds are } \\
\text { distributed uniformly. }\end{array}$ \\
\hline 8 & Mattaneng & $\begin{array}{c}\text { Manually planting using certain spacings. Farmers take turns and work together to plant on their } \\
\text { respective lands or to exchange labor. }\end{array}$ \\
\hline 9 & Maddongi & $\begin{array}{c}\text { Farmers repel sparrows by shouting or using tools that frightens the sparrows called scarecrows } \\
\text { (Pajo-Pajo). The scarecrows are wrapped in cans filled with pebbles or stones; thus, when the Pajos are } \\
\text { shaken, the birds are surprised and fly from the fields. }\end{array}$ \\
\hline 10 & Manggepik Ase & $\begin{array}{l}\text { Spraying the herbs over the plants to control the green leafhoppers, using ingredients composed of } \\
\text { galangal leaves, kariango leaves, ginger, and coconut water. It is generally accompanied with prayers or } \\
\text { rituals to protect the rice from pests and diseases. }\end{array}$ \\
\hline 11 & Mengngala & $\begin{array}{l}\text { Harvesting activities carried out by individual farmers using a tool called a Rakkapeng. Harvesting is } \\
\text { done as mutual cooperation of all residents and all age groups. On the day before the harvest, Sanro } \\
\text { Wanua walks through the rice fields of a village (Wanua) to see if the rice has turned yellow, indicating } \\
\text { that the rice is ready to be harvested. The harvest is first carried out by Sanro Wanua, who symbolically } \\
\text { marks the start of the harvest and subsequent harvesting activities. }\end{array}$ \\
\hline
\end{tabular}

\subsection{IK Indicators of Seasonal Rainfall Forecasting}

Local communities around the world observe living creatures and dead entities in order to predict the future and the current weather variables. With repeated observations of biophysical proxies and the events associated with these observations, predictions, feedback, and readjusting relationship cycles, it is possible to safely predict the future (albeit not quantifiably). All forms of outcomes including a rainy season, a drought, and a windy season are considered as good lessons that help indigenous people to be better attuned with their environment and make them more capable of understanding and predicting future weather and climate events [24].

Bugis-Makassar farmers plan the cultivation of rice through Lontara Allaorumang's book, which discusses traditional knowledge linked to agricultural systems based on natural phenomena, especially plant phenology and animal behavior, as well as celestial phenomena studied over a long period of time (Table 4). The results show that farmers use a combination of biological and celestial indicators to forecast seasonal weather conditions and make important rice farming decisions. Traditionally, these indicators trigger the start of farming-related activities depending on the significance of the indicator. Therefore, the Bugis-Makassar people can understand and be aware of those changes closely related to abnormal weather. In fact, the use of fauna and flora for weather forecasting is applied by many indigenous groups or small farmers over the world, especially those who have a weak connection to science-related information on weather forecasting [26,31]. 
Table 4. Traditional indicators for seasonal changes of the Bugis-Makassar tribe.

\begin{tabular}{|c|c|}
\hline Indicator & Significance \\
\hline \multicolumn{2}{|c|}{ Plants phenology } \\
\hline $\begin{array}{l}\text { Banana petals fall and face up, bamboo shoots (not yet widely) } \\
\text { become longer/bigger than the parent, and mango plants bear fruit } \\
\text { twice a year. }\end{array}$ & Plenty of rainy days in 1 year \\
\hline $\begin{array}{l}\text { Significant amount of guava fruit grows in the forest and the fruits } \\
\text { are not attacked by pests. }\end{array}$ & Rice will be harvested safely without risk of pests. \\
\hline \multicolumn{2}{|c|}{ Animal behavior } \\
\hline Rat holes are found in the middle to the top of the embankment. & Heavy rains (floods) and plenty of rainy days. \\
\hline Rat holes are found in the middle of the rice field. & A long dry season will take place. \\
\hline $\begin{array}{l}\text { Red ants are outside their nests and move to higher locations within } \\
\text { the groups. Plenty of fish at the edges of lake, river, or sea. }\end{array}$ & $\begin{array}{l}\text { There are going to be heavy rains and floods causing } \\
\text { abundance; thus, rice is suitable for planting. }\end{array}$ \\
\hline \multicolumn{2}{|c|}{ Celestial indicator } \\
\hline A star shines brightly around 7:00 p.m. & Rainfall is abundant and the rainy days are lengthy. \\
\hline $\begin{array}{l}\text { There are seven stars close to each other with bright lights that } \\
\text { appear around 11:00 p.m. and set before dawn. }\end{array}$ & The rains are abundant, and the number of wet days is long. \\
\hline $\begin{array}{l}\text { Four stars appear in the west in the form of a parallelogram at } \\
\text { approximately 7:00 p.m. }\end{array}$ & $\begin{array}{l}\text { There will be plenty of rain. If the shape turns into to a } \\
\text { rectangle, it means the rain will stop. }\end{array}$ \\
\hline $\begin{array}{l}\text { The crescent-shaped moon at the time of its appearance faces north } \\
\text { and occurs the first night until the seventh night. }\end{array}$ & There will be a lot of wet days and heavy rainfall that year. \\
\hline
\end{tabular}

However, the IK is slowly disappearing and being eroded, and this ultimately raises the question of how much longer the system can sustain itself. In line with this finding, previous researchers found the decline in or loss of IK over recent years to be the dominant trend in many parts of the world [47-49]. It is believed that this is due to the changing nature of knowledge, as the elderly are being replaced by the young and middle-aged, who seem to be more concerned with modernization than taking up this knowledge. Furthermore, many studies have shown a correlation between age and knowledge [50], which suggests that knowledge accumulates with age and decreases with each successive generation [51,52]. The challenges facing IK seasonal forecasting include a poor knowledge transfer system, insufficient documentation, death of forecast experts, and influence of modern education. Other factors threatening IK indicators include the extinction of some plants and animals, destruction of vegetation resulting from rapid urbanization, and high population growth [27].

Given this background, we suggest that a systematic documentation of the IK indicator is required in the near future if these indicators are to be preserved as a basis for decision making. Furthermore, an in-depth analysis is needed in order to understand how the IK indicators are used for forecasting and the context in which the indicators are used. This also includes investigating the accuracy, reliability, and validity of IK indicators for seasonal climate forecasting.

\subsection{Farmer's Understanding of IK in Rice Farming Practices}

In response to their opinions on the IK in rice farming according to the semi-structured interview, it can be assumed that all 36 respondents had knowledge about IK practices, as described in Figure 4. Meanwhile, all 36 respondents completed the interview. It can be seen that most of the respondents had a low education status; however, they were able to understand and answer the questions. Table 5 provides detailed background characteristics of the respondents. 

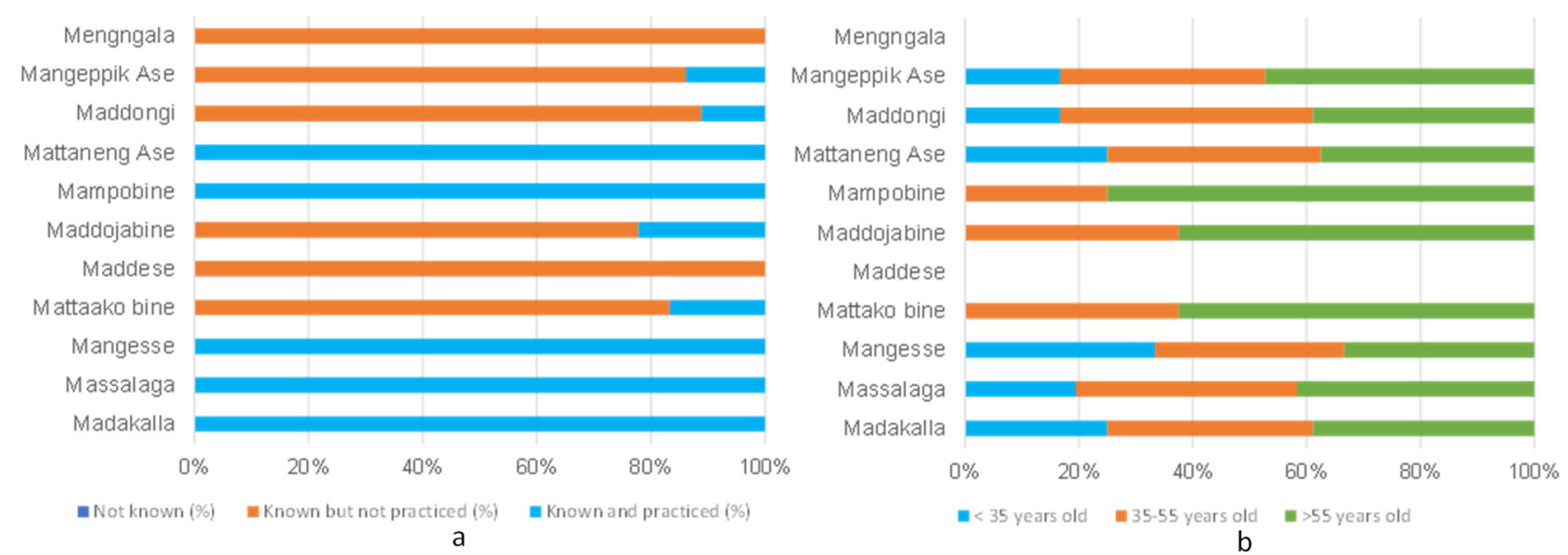

Figure 4. Farmer respondents' understanding of IK in rice farming practices (a) and application of IK in rice farming practices as a function of farmer age group (b).

Table 5. Background characteristics of respondents.

\begin{tabular}{ccc}
\hline Item & Number $(\boldsymbol{n}=\mathbf{3 6})$ & Percentage \\
\hline Gender & 32 & \\
\hline Male & 4 & $89 \%$ \\
Female & & $11 \%$ \\
\hline Age & 8 & \\
\hline$<35$ & 18 & $22 \%$ \\
$35-55$ & 10 & $50 \%$ \\
$>55$ & & $28 \%$ \\
\hline Marital status & 9 & \\
\hline Single & 27 & $25 \%$ \\
Married & & $75 \%$ \\
\hline Education & 12 & $22 \%$ \\
\hline Primary school & 14 & $50 \%$ \\
Secondary school & 10 & $28 \%$ \\
High school & 0 & $0 \%$ \\
University & &
\end{tabular}

According to the interview, two of the 11 rice farming activities, namely Mengngala (harvesting using Rakkapeng) and Maddese (seed separation), are no longer practiced, even though respondents were familiar with these activities. The use of Rakkapeng for harvesting has been replaced by using a hand tractor, while Maddase is no longer needed because farmers already use labeled seeds.

The involvement of farmers under the age of 35 was very limited to some activities, especially those related to pest control such as Maddongi and Manggepik Ase. Young farmers were more engaged in activities related to planting (Mattaneng) and land preparation (Mangesse). With the development of technology, some IK in rice cultivation has begun to erode because technology has made all jobs easier and more convenient. They are applied within a short time frame, thereby increasing rice production.

On the other hand, most of the indigenous farmer practices and knowledge at the different stages of agricultural activities are cheap and easy to obtain. Moreover, most export markets now prefer organic foods produced by this category of farmers, and this offers them an opportunity to improve their income. Most IK of the Bugis-Makassar tribe in rice farming practices is still ongoing because the Tudang Sipulung event still takes 
place at the village and district level. This could be incorporated into research to enrich the research process and make it more relevant for the farmers.

\subsection{Tudang Sipulung}

Prior to planting rice, the Bugis-Makasssar community practices a culture deliberation that involves making decisions while sitting together, which is known as Tudang Sipulung. Tudang Sipulung conducted at the village level is led by the village head and attended by community leaders, Pallontara/Pappananrang, head of farmer groups, extension workers, observers of plant pest organisms (POPT), farmers, chairman of the Water User Farmers Association (P3A), and head of the Agricultural Extension Center (BPP).

Pallontara and Pappananrang propose the suitable time to sow seeds such that the need for rainfall and sunlight is satisfied, and they anticipate the likelihood of pests and diseases attacking the rice. On the basis of the results of the discussion, the village head makes notes regarding the planting time, type of variety, and the need for the amount of seed and fertilizer to be submitted at the Tudang Sipulung event at the district level about 1-2 weeks later. Before Tudang Sipulung is implemented, agricultural activities in the rice fields are not undertaken by the agricultural community.

The Tudang Sipulung event in the district is led by the Regent and attended by Pallontara and Pappananrang, the heads of the relevant agencies (namely, head of the Assessment Institute for Agricultural Technology (BPTP), head of the Meteorology, Climatology, and Geophysics Agency (BMKG), head of the Center for Food Crops and Horticulture Protection, head of Bank Units (BRI/BNI), head of Pupuk Sriwijaya (ferlilizer producer), head of P3A), the Farmers' Union, researchers, and extension workers. The stages of the implementation of Tudang Sipulung are described in Figure 5.
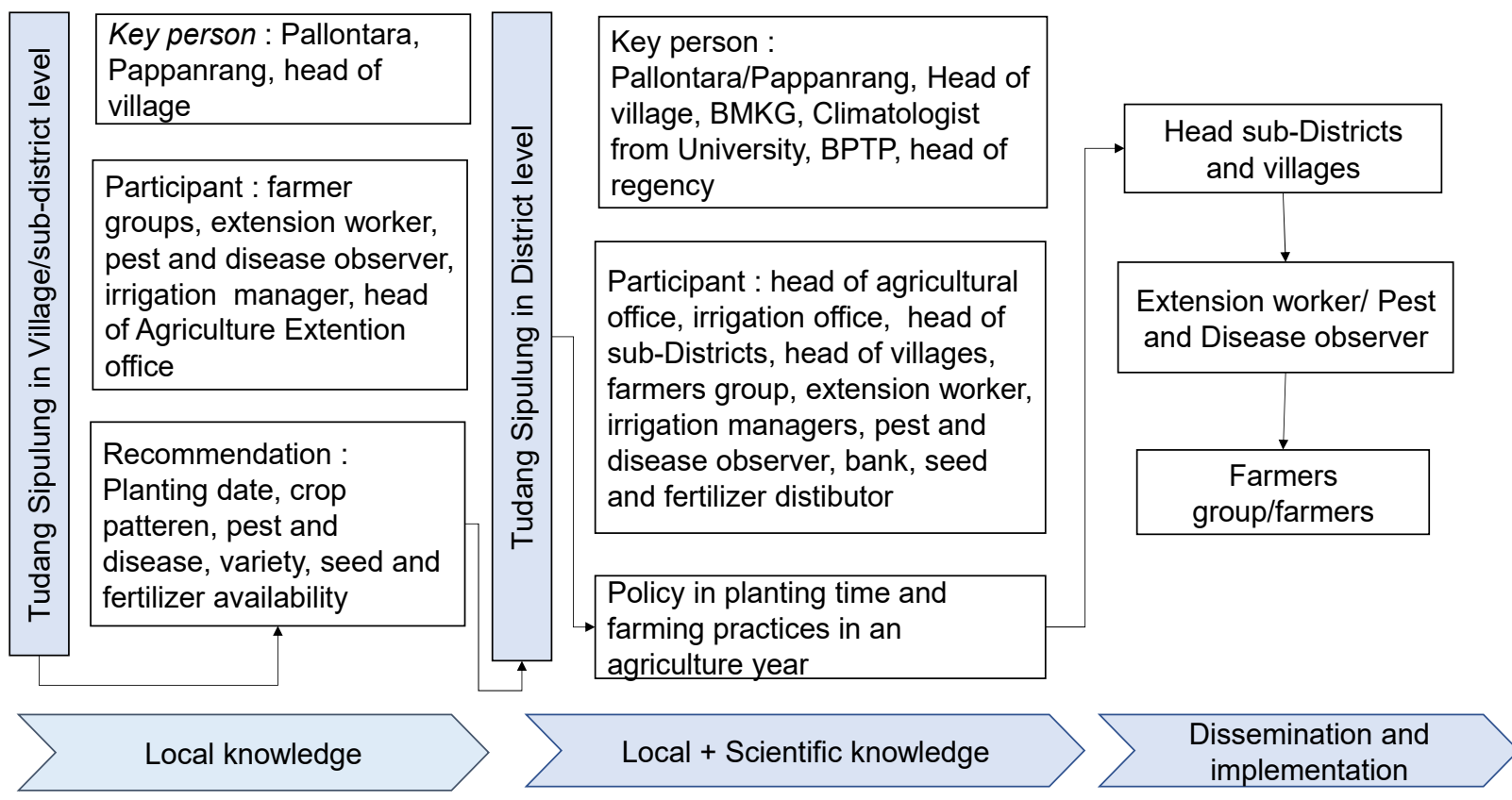

Figure 5. Scheme of Tudang Sipulung at the subdistrict/district levels and decision implementation.

\subsection{Integration of Local and Scientific Knowledge in Rice Farming in South Sulawesi}

Tudang Sipulung is a true example of the integration of local knowledge and scientific knowledge related to the rice farming system. In the Tudang Sipulung event at the district level, the BMKG delivers rainfall forecasts for the next 6 months, especially regarding the beginning of the rainy season, the nature, and the seasonal changes related to agricultural business. Pallontara and Pappananrang convey the agreement at the village level, while researchers of the BPTP convey the recommended planting time according to the ICCIS recommendation, the availability of the latest cultivation technology, types of quality rice 
varieties, and pest and disease control technology. Meanwhile, the POPT reports the probability of pests and diseases attacking rice fields.

The recommended planting time delivered by BPTP is accessed from the ICCIS website. Researchers of BPTP are members of the task force team of the ICCIS. The task force team is responsible for disseminating the ICCIS to farmers and extension workers, in collaboration with other agencies in the regions, such as the BMKG, extension offices, and agricultural offices [46].

The agreement on planting period and cultivation practices is reached on the basis of an agreement among Pallontara, Pappananrang, BMKG, POPT, and BPTP. The Tudang Sipulung event results in several conclusions, including (1) the onset of planting time based on Pallontara/Pappananrang, BMKG predictions, and ICCIS recommendations, (2) variety types agreed to be planted on the basis of pest and disease forecasts and rainfall, (3) prediction of pests and diseases that are likely to appear according to suggestions from Pallontara/Pappananrang and researchers from the BPTP and POPT, (4) rice cultivation techniques such as spacing and fertilization, and harvesting and post-harvesting, (5) yearly cropping patterns, and (6) availability of facilities and infrastructure for farming systems.

The difference that often takes place includes the right time of planting according to Pallontara/Pappananrang, BMKG predictions, and the planting time recommended by the BPTP. If the recommended planting time differs, there are discussions and arguments. If the two arguments are strong, then common ground is reached between the two planting periods. However, if a party's argument is more persuasive, then the planting time of that party's proposal is agreed upon.

Through this agreement, the planting time and variety type can be standardized to ensure that pests can be properly controlled through collective action. This can be done by making use of irrigation water more efficiently. As a guide to cultivating rice the following year for the rainy and dry seasons, the agreement is compiled in the form of a book called Tudang Sipulung, and the manual is distributed to the subdistrict head, village head, extension workers, and POPT for transmission to the farming community.

In the case when there is a village with unique resource conditions that are different from those of other villages and it is difficult to comply with agreed recommendations, then the implementation of the Tudang Sipulung agreement is left to the head of the village to decide, depending on local conditions. For example, in Wette Village in Sidrap District, the rain characteristics are more similar to those in Soppeng. The start of the rainy season in the village is in December-January. Meanwhile, the beginning of the rainy season in Sidrap District is predominantly in April-May. For these areas, the decision on planting time and the technology package to be applied is left to the village head to decide.

In the event that certain parties and/or members of the community fail to comply with the outcome of the Tudang Sipulung agreement, social-institutional sanctions are applied (e.g., not receiving support for agriculture facilities and infrastructure). At the village level, the head of the village gives the penalty in the form of a fine of one bucket of grain, cleaning of irrigation water canals, and cutting of chickens or goats to eat together, which is called Macekrak.

The local culture of Tudang Sipulung has been practiced since ancient times and is currently being facilitated by the Province of South Sulawesi government. The difference between Tudang Sipulung (currently under implementation) and what was previously practiced by the farmers is that it incorporates local knowledge with scientific knowledge into decision- making. Decisions are made on the basis of an understanding between the government and farmers according to shared interests. In addition, the Tudang Sipulung agreement is a guideline that should be respected and followed in future agricultural management. Moreover, through the Tudang Sipulung event, the local government also broadcasts local government programs and national policies. Tudang Sipulung's decisions have been found to be highly effective in increasing rice production and reducing the risk of drought and pest attacks. As a result, Tudang Sipulung has been expanded to Wajo, Takalar, Bone, and other districts in South Sulawesi, previously being practiced only by the 
Sidrap community. The benefits of Tudang Sipulung have enabled this event to continue and be supported by the government.

\subsection{Future Challenges}

One of the research outcomes of the Indonesian Agricultural Research and Development Agency that has been widely used and is readily accessible is the ICCIS. The ICCIS describes potential planting time patterns for food crops, particularly rice, maize, and soybeans, according to climate and water resources [53]. The use of information on planting time, in combination with other information such as areas prone to flood, and drought and pest attacks, as well as varieties, fertilizer recommendations, availability of farm machinery, and feed adequacy, may serve as a reference for decision makers in the preparation of food crop management [54]. The ICCIS is also equipped with information to support the agriculture system and minimize climate hazards. The information includes (a) fertilizer recommendations, (b) agricultural machinery availability, (c) potential livestock feed, (d) potential crops damaged due to flood, drought, pests, and diseases, and (e) variety recommendations [46]. The same information is discussed in the Tudang Sipulung to decide the planting time and rice farming practices for the upcoming growing season.

An example of incorporating local knowledge into scientific knowledge is to confirm the outcomes of ICCIS recommendations for planting time and predictions of Pallontara/Pappanarang planting times in the Tudang Sipulung event. The planting time in the ICCIS is built using information on the start of the BMKG rainy season and water balance analysis to determine the appropriate planting time, depending on the availability and water needs of the crops. Similarly, recommendations for potential floods, droughts, and outbreaks of plant pests and diseases are also available from the ICCIS. Recommendations on the planting timeframe resulting from the Tudang Sipulung agreement with the ICCIS planting timeframe for wet season planting (WSP) and dry season planting (DSP) for the 2018-2021 period are detailed in Table 6.

The recommendations for the planting period agreed by Tudang Sipulung and the ICCIS for the period 2018-2021 were largely identical, because both used the seasonal forecast from BMKG. The difference is that the Tudang Sipulung planting time agreement uses local wisdom taking into account the BMKG predictions, whereas the ICCIS uses BMKG forecasts as an input for water balance analysis. Differences in planting time recommendations occurred for DSP 2019 and DSP 2021 in the Takkalalla Subdistrict of Wajo District. The recommended planting time according to Tudang Sipulung was one to two decades earlier. For the Panca Lautang Subdistrict, differences occurred for the recommended planting time for WSP 2019/2020 and WSP 2020/2021, which was two decades earlier and two decades later, respectively. The recommended planting time for Gallesong Subdistrict of Takalar District was the same during this period. The planting time recommendations for the Tellu Settianngeng Subdistrict of Bone District were different for the 2019 DSP, 2020/2021/WSP, and 2021 DSP, following Tudang Sipulung's recommendations of one decade (10 days) earlier.

By practicing rice cultivation according to the Tudang Sipulung agreement, especially if there are differences, it is very important to make a decision that can be accepted by all parties. Therefore, to avoid conflict in decision making, identifying appropriate ways to work with indigenous and scientific knowledge is critical to the success of knowledge partnerships [55]. According to Wheeler et al. [56], most importantly, consultation and collaboration processes can determine how the knowledge is collected and used, which is acceptable to all parties. 
Table 6. Comparison of the onset of wet season planting (WSP) and dry season planting (DSP) recommendations of Tudang Sipulung at the district level and of the ICCIS.

\begin{tabular}{|c|c|c|c|}
\hline Subdistrict & Season Planting & Tudang Sipulung & ICCIS \\
\hline \multirow{6}{*}{$\begin{array}{c}\text { Takalalla, Wajo } \\
\text { District }\end{array}$} & WSP 2018/2019 & Nov II-Nov III & Nov III-Dec I \\
\hline & DSP 2019 & Apr III-May I & May I-II \\
\hline & WSP 2019/2020 & Sep III-Oct I & Sep III-Oct I \\
\hline & DSP 2020 & Apr II-III & Apr II-III \\
\hline & WSP 2020/2021 & Nov II-Nov III & Nov II-III \\
\hline & DSP 2021 & Apr III-May II & May II-III \\
\hline \multirow{6}{*}{$\begin{array}{l}\text { Panca Lautang } \\
\text { (Sidrap District) }\end{array}$} & WSP 2018/2019 & Nov III-Dec I & Nov III-Dec I \\
\hline & DSP 2019 & Apr II-III & Apr II-III \\
\hline & WSP 2019/2020 & Nov III-Dec I & Dec II-III \\
\hline & DSP 2020 & Apr II-III & April II-III \\
\hline & WSP 2020/2021 & Nov III-Dec I & Nov I-II \\
\hline & DSP 2021 & Apr II-III & Apr II-III \\
\hline \multirow{6}{*}{$\begin{array}{c}\text { Galessong, } \\
\text { Takalar District }\end{array}$} & WSP 2018/2019 & Nov III-Dec I & Nov III-Dec I \\
\hline & DSP 2019 & Secondary crop/fallow & Secondary crop/fallow \\
\hline & WSP 2019/2020 & Nov III-Dec I & Nov III-Dec I \\
\hline & DSP 2020 & Secondary crop/fallow & Secondary crop/fallow \\
\hline & WSP 2020/2021 & Dec II-III & Dec II-III \\
\hline & DSP 2021 & Mar III-Apr I & Mar III-Apr I \\
\hline \multirow{6}{*}{$\begin{array}{c}\text { Tellu } \\
\text { Settiangngeng, } \\
\text { Bone District }\end{array}$} & WSP 2018/2019 & Nov III-Dec I & Nov III-Dec I \\
\hline & DSP 2019 & Apr III-May I & May I-II \\
\hline & WSP 2019/2020 & Dec II-III & Dec II-III \\
\hline & DSP 2020 & Apr II-III & Apr II-III \\
\hline & WSP 2020/2021 & Dec III-Jan I & Jan I-II \\
\hline & DSP 2021 & Apr III-May I & May I-II \\
\hline
\end{tabular}

Note: Roman letters behind the month indicate decadal values (accumulated 10 days); I, II, and III denote the first 10 days, second 10 days, and third 10 days of a month.

The consistent implementation of the Tudang Sipulung agreement by the local government is an effort to preserve local wisdom as a culture and cultural identity of a region, tribe, and community group. The legitimacy and credibility of science is most evident to scientists, while indigenous or local knowledge is most evident to the indigenous and local knowledge holders. Those who bridge the integration process need to have particular value [57], whereby local governments can implement binding regulations.

Decision making through the participation of scientific institutions such as the BMKG, researchers, and pest observers is an integration of local wisdom and scientific knowledge. This integration of traditional and modern systems requires a shared understanding of cultural and scientific material [43]. Integration of the ICCIS is an interesting challenge in enriching the sources of information in Tudang Sipulung's decision making. According to Castro and Nielsen [58], a collaboration between the IK holders and policymakers could provide an excellent opportunity to resolve or avoid resource management conflicts. In addition, the involvement of agricultural extension workers and farmer groups is very important in agricultural development intervention [59,60] for transmitting IK technologies, practices, and problems from farmers to policymakers and researchers [61].

The ICCIS, as one of the research outcomes of the Indonesian Agricultural Research and Development Agency, is widely used and well known by extension workers, and it can be integrated with IK of the Bugis-Makassar tribe for adjusting planting time and implementing rice farming practices. Local engagement in research may increase the capacity to influence decisions and accelerate their implementation $[29,30]$. With respect to Tudang Sipulung, it is best to engage young farmers who understand information technologies and their implementation in agriculture, such as the ICCIS. Additionally, opportunities for young farmers to learn about local wisdom in rice farming practices should be provided. 


\section{Conclusions}

The indigenous knowledge of the Bugis-Makassar farming communities is implemented independently without the support of other sources outside the community, which is still developing and is being used today, despite being undermined by the development of science and technology.

The Bugis-Makassar people plan the cultivation of rice using traditional indicators such as crop phenology, animal behavior, and star constellations. However, the IK is slowly disappearing and is being replaced by middle-aged people and young people, who seem more concerned with modernization than with access to this knowledge. Fortunately, most IK practices are still ongoing because the Tudang Sipulung event is still happening to achieve a mutual agreement to determine planting time, applied cultivation technology, variation of pest and disease control, and harvesting and post-harvest activities by incorporating local wisdom and the ICCIS as scientific knowledge.

Tudang Sipulung's strength lies in the government's participation in integrating IK and scientific knowledge into formal forums involving the government and farming communities. The agreement of Tudang Sipulung is formally binding with the decision of the Regent and the constitutional sanctions imposed on those who do not comply. Furthermore, the Tudang Sipulung agreement encourages the community to practice IK in rice cultivation and implement science-based technology. In order to provide optimal benefits, it is recommended to engage young farmers and pay attention to aspects of gender equality. The participation of young farmers in understanding and preserving IK and scientific knowledge is necessary to preserve local culture and transfer modern technology.

Future research to develop more collaborative work and coproduction between indigenous people and decision makers to continually improve the integration of IK and scientific knowledge will be the key to the effectiveness of Tudang Sipulung. It is particularly important to provide more training to scientists to incorporate the concepts of indigenous knowledge, given the number of researchers attracted to future collaborations with indigenous communities.

Author Contributions: Conceptualization, S.Y.L., I.M.F. and H.S.; methodology, S.Y.L. and E.S.; A.F., A.W.R., M. and S.; software, E.S. and K.B.A.; validation, A.F., A.W.R. and M.; formal analysis, I.M.F., E.S. and A.F.; investigation, S.Y.L., E.S., A.F. and A.W.R.; resources, S.Y.L., I.M.F. and K.B.A. and E.S.; data curation, A.F. and A.W.R.; writing-original draft preparation, S.Y.L., I.M.F., E.S., S. and M.; writing-review and editing, S.Y.L., E.S., A.F., A.W.R., S. and M.; visualization, E.S.; supervision, I.M.F. and K.B.A.; project administration, A.W.R.; funding acquisition, H.S. All authors have read and agreed to the published version of the manuscript.

Funding: This research was funded by the Indonesia Agency for Agricultural Research and Development, Ministry of Agriculture, grant number 1809.EBA.958.052B.

Institutional Review Board Statement: Not applicable.

Informed Consent Statement: Informed consent letter was obtained from all subject involved in the study.

Data Availability Statement: Not applicable.

Conflicts of Interest: The authors declare no conflict of interest.

\section{References}

1. Tirivangasi, H.M.; Tayengwa, D. Indigenous Knowledge Systems (IKS) and Food Security in South Africa: Is Land Reform a Prerequisite? J. Hum. Ecol. 2017, 57, 118-124. [CrossRef]

2. Levis, L.R.; Sukesi, K.; Yuliati, Y. Farmers Behaviour Regarding Food Security by Practicing the Salome Farming System as Local Wisdom in West Timor. East Nusa Tenggara Province, Indonesia. Trop. Subtrop. Agroecosyst. 2017, 20, $231-237$.

3. Septanti, K.S.; Saptana, N. Potensi Pemanfaatan Kearifan Lokal untuk Menahan Konversi Lahan Sawah ke Nonsawah. Forum Penelit. Agro Èkon. 2020, 37, 59-75. [CrossRef] 
4. Sumartias, S.; Unde, A.A.; Wibisana, I.P.; Nugraha, A.R. The Importance of Local Wisdom in Building National Character in the Industrial Age 4. In Proceedings of the 3rd International Conference on Learning Innovation and Quality Education (ICLIQE 2019); Atlantis Press: Paris, France, 2020; pp. 1305-1312.

5. Syahruna, A.R.; Yusoff, R.; Amin, M. Peranan Budaya Tudang Sipulung/Appalili dan Faktor-faktor yang Mempengaruhi Bergesernya Nilai Budaya Pertanian di Sulawesi Selatan. SOSIOHUMANIKA 2014, 7, 16.

6. Kartika, T. Verbal Communication Culture and Local Wisdom: The Value Civilization of Indonesia Nation. Lingua Cult. 2016, 10, 89. [CrossRef]

7. Haverkort, B.; de Zeew, H. Development of Technologies toward Sustainable Agriculture: Institutional Implications In Agricultural Extension: World Wide Institutional Evolution and Forces for Change; Elsevier Science Publishing Company: New York, NY, USA, 1992; pp. 231-242.

8. Butler, L.; Waud, J. Strengthening Extension through the Concepts of Farming Systems Research and Extension (Fsr/e) and Sustainability. J. Farming Syst. Res. Ext. 1990, 1, 77-98.

9. Husnah, N.; Ali, M.S.S.; Salman, D. Merging Indigenous and Modern Knowledge in Agricultural Development. Int. J. Agric. Syst. 2014, 2, 141-151.

10. Sulawesi Selatan, S. Result of Inter-Censal Agricultural Survey 2018 of Sulawesi Selatan Province; BPS-Statistic of Sulawesi: Makassar Indonesia, 2019. (In Indonesia)

11. Marzuki, A.A. Reflecting the Reflective Journal Training in South Sulawesi, Indonesia: The Case of Secondary Teachers from Bugis Ethnic Group. In Proceedings of the AARE Annual Conference, Adelaide, Australia, 29 January-1 February 2013; pp. 1-17.

12. Rudi, R.; Ln, S.Y. Tudang Sipulung: Integrating South Sulawesi local wisdom into learning practice in teacher learning community. In Proceedings of the 3rd Asian Education Symposium (AES 2018); Atlantis Press: Paris, France, 2019; pp. 88-91.

13. Kamaluddin, A.; Husnah, N.; Busthanul, N.; Ali, M.S.S. "Pananrang”: A Guidance of Buginese Farmers in Farming. Int. J. Agric. Syst. 2016, 4, 168. [CrossRef]

14. Arifin, I. Good governance and regiomal development in the framework of local wisdom: Astudy of bureaucracy and social political change in Wajo District (in Indonesia). Gov. J. Ilmu Pemerintah. 2009, 2, 63-80.

15. Maeda, N. Agricultural Rites in South Sulawesi. Southeast Asian Stud. 1991, 28, 535-543.

16. Acciaioli, G. What's in a Name? Appropriating Idioms in the South Sulawesi Rice Intensification Program. Int. J. Soc. Cult. Pract. 1994, 35, 39-60.

17. Nuh, M.S. Tudang Sipulung: A Conflict Resolution Wisdom of Bugis-Makassar Community. Hasanuddin Law Rev. 2016, 1, 241. [CrossRef]

18. Finucane, M. Why Science Alone Won't Solve the Climate Crisis: Managing the Climate Risks in the Pacific. Asia Pac. Issues 2009, $89,1-8$.

19. Mafongoya, P.L.; Ajayi, O.C. Indigenous Knowledge Systems and Climate Change Management in Africa; CTA: Wageningen, The Netherlands, 2017.

20. Warren, D.M. Putting Local Knowledge to Good Use. Int. Agric. Dev. 1993, 13, 8-10.

21. Abedi, M.; Khodamoradi, S. The Role of Agricultural Extension in Integrating Indigenous Knowledge and Modern Knowledge in Rural. Life Sci. J. 2011, 8, 254-258.

22. Chisenga, J. Indigenous knowledge: Africa's opportunity to contribute to global information content. S. Afr. J. Libr. Inf. Sci. 2013, 68, 759. [CrossRef]

23. Sillitoe, P. Indigenous Knowledge in Development. Anthr. Action 2006, 13, 1-12. [CrossRef]

24. Balehegn, M.; Balehey, S.; Fu, C.; Liang, W. Indigenous weather and climate forecasting knowledge among Afar pastoralists of north eastern Ethiopia: Role in adaptation to weather and climate variability. Pastoralism 2019, 9, 8. [CrossRef]

25. Mbewe, M.; Phiri, A.; Siyambango, N. Indigenous Knowledge Systems for Local Weather Predictions: A Case of Mukonchi Chiefdom in Zambia. Environ. Nat. Resour. Res. 2019, 9, 16. [CrossRef]

26. Radeny, M.; Desalegn, A.; Mubiru, D.; Kyazze, F.; Mahoo, H.; Recha, J.; Kimeli, P.; Solomon, D. Indigenous knowledge for seasonal weather and climate forecasting across East Africa. Clim. Chang. 2019, 156, 509-526. [CrossRef]

27. Mapfumo, P.; Mtambanengwe, F.; Chikowo, R. Building on indigenous knowledge to strengthen the capacity of smallholder farming communities to adapt to climate change and variability in southern Africa. Clim. Dev. 2016, 8, 72-82. [CrossRef]

28. Kangalawe, R.; Mwakalila, S.; Masolwa, P. Climate Change Impacts, Local Knowledge and Coping Strategies in the Great Ruaha River Catchment Area, Tanzania. Nat. Resour. 2011, 2, 212-223. [CrossRef]

29. Son, H.N.; Chi, D.T.L.; Kingsbury, A. Indigenous knowledge and climate change adaptation of ethnic minorities in the mountainous regions of Vietnam: A case study of the Yao people in Bac Kan Province. Agric. Syst. 2019, 176, 102683. [CrossRef]

30. Van Huynh, C.; Le, Q.N.P.; Nguyen, M.T.H.; Tran, P.T.; Nguyen, T.Q.; Pham, T.G.; Nguyen, L.H.K.; Nguyen, L.T.D.; Trinh, H.N. Indigenous knowledge in relation to climate change: Adaptation practices used by the Xo Dang people of central Vietnam. Heliyon 2020, 6, e05656. [CrossRef] [PubMed]

31. Kijazi, A.L.; Chang'a, L.B.; Liwenga, E.T.; Kanemba, A.; Nindi, S.J. The use of indigenous knowledge in weather and climate prediction in Mahenge and Ismani wards, Tanzania. J. Geogr. Reg. Plan. 2013, 6, 274-279. [CrossRef] 
32. Rankoana, S.A. Subsistence Food Production Practices: An Approach to Food Security and Good Health. Int. J. Environ. Res. Public Health 2017, 14, 1184. [CrossRef]

33. Nyadzi, E.; Werners, S.E.; Biesbroek, R.; Ludwig, F. Towards weather and climate services that integrate indigenous and scientific forecasts to improve forecast reliability and acceptability in Ghana. Environ. Dev. 2022, 100698, 100698. [CrossRef]

34. Ruzol, C.; Lomente, L.L.; Pulhin, J. Cultural consensus knowledge of rice farmers for climate risk management in the Philippines. Clim. Risk Manag. 2021, 32, 100298. [CrossRef]

35. Irangani, M.; Shiratake, Y. Indigenous Techniques Used in Rice Cultivation in Sri Lanka: An Analysis from an Agricultural History Perspective. Indian J. Tradit. Knowl. 2013, 12, 638-650.

36. Waithaka, M. The Role of Indigenous Knowledgein Sustainable Food Production: A Case of Post-Harvest Practices in Maize Preservation in Mua Hill Location, Eastern Kenya; Van Hall Larenstein University of Applied Science: Leeuwarden, The Netherlands, 2011.

37. Wang, J. Integrating Indigenous with Scientific Knowledge for the Development of Sustainable Agriculture: Studies in Shaanxi Province. Asian J. Agric. Dev. 2015, 15, 41-58.

38. Altieri, M.A.; Nicholls, C.I. The adaptation and mitigation potential of traditional agriculture in a changing climate. Clim. Chang. 2013, 140, 33-45. [CrossRef]

39. Norgaard, R.B. Coevolutionary Development Potential. Land Econ. 1984, 60, 160. [CrossRef]

40. Toenniessen, G.; Adesina, A.; Devries, J. Building an Alliance for a Green Revolution in Africa. Ann. N. Y. Acad. Sci. 2008, 1136, 233-242. [CrossRef]

41. Juma, C. The New Harvest: Agricultural Innovation in Africa, 2nd ed.; Oxford University Press: New York, NY, USA, 2015.

42. Mellor, J.W. Agricultural Development and Economic Transformation; Springer Science and Business Media LLC: Berlin, Germany, 2017.

43. Agrawal, A. Dismantling the Divide Between Indigenous and Scientific Knowledge. Dev. Chang. 1995, 26, 413-439. [CrossRef]

44. Mercer, J.; Kelman, I.; Taranis, L.; Suchet-Pearson, S. Framework for integrating indigenous and scientific knowledge for disaster risk reduction. Disasters 2010, 34, 214-239. [CrossRef]

45. Mistry, J.; Berardi, A. Bridging Indigenous and Scientific Knowledge Local Ecological Knowledge Must Be Placed at the Center of Environmental Governance. Science 2016, 352, 1275-1276.

46. Apriyana, Y.; Surmaini, E.; Estiningtyas, W.; Pramudia, A.; Ramadhani, F.; Suciantini, S.; Susanti, E.; Purnamayani, R.; Syahbuddin, $\mathrm{H}$. The Integrated Cropping Calendar Information System: A Coping Mechanism to Climate Variability for Sustainable Agriculture in Indonesia. Sustainability 2021, 13, 6495. [CrossRef]

47. Hanazaki, N.; Herbst, D.F.; Marques, M.S.; Vandebroek, I. Evidence of the shifting baseline syndrome in ethnobotanical research. J. Ethnobiol. Ethnomed. 2013, 9, 75. [CrossRef]

48. Aswani, S.; Lemahieu, A.; Sauer, W.H.H. Global trends of local ecological knowledge and future implications. PLoS ONE 2018, 13, e0195440. [CrossRef]

49. Okui, K.; Sawada, Y.; Yoshida, T. "Wisdom of the Elders" or "Loss of Experience" as a Mechanism to Explain the Decline in Traditional Ecological Knowledge: A Case Study on Awaji Island, Japan. Hum. Ecol. 2021, 49, 353-362. [CrossRef]

50. Sujarwo, W.; Arinasa, I.B.K.; Salomone, F.; Caneva, G.; Fattorini, S. Cultural Erosion of Balinese Indigenous Knowledge of Food and Nutraceutical Plants. Econ. Bot. 2014, 68, 426-437. [CrossRef]

51. Reyes-García, V.; Luz, A.C.; Gueze, M.; Paneque-Gálvez, J.; Macia, M.J.; Martinez, M.O.; Pino, J. Secular Trends on Traditional Ecological Knowledge: An Analysis of Changes in Different Domains of Knowledge among Tsimane' Men. Learn. Individ. Differ. 2013, 27, 206-2112. [CrossRef] [PubMed]

52. Koster, J.; Bruno, O.; Bunrs, J.L. Wisdom of the Elders? Ethnobiological Knowledge across the Lifespan. Curr. Anthropol. 2016, 57, 113-121. [CrossRef]

53. Runtunuwu, E.; Ramadhani, F.; Setyorini, D.; Haryanti, K.; Apriyana, Y.; Susanti, E.; Haryono, S. Institutional Innovation of Integrated Cropping Calendar Information System to Support Climate Change Adaptation for National Food Security. Pengemb. Inov. Pertan 2013, 6, 44-52.

54. Runtunuwu, E.; Syahbuddin, H.; Ramadhani, F.; Pramudia, A.; Setyorini, D.; Haryanti, K.; Apriyana, Y.; Susanti, E.; Haryono, S.; Setyanto, P. Integrated Cropping Calendar Information System: Current Status and Future Challenges. J. Sumberd. Lahan 2012, 6, 67-78.

55. Watson, A. Misunderstanding the "Nature" of Co-Management: A Geography of Regulatory Science and Indigenous Knowledges (IK). Environ. Manag. 2013, 52, 1085-1102. [CrossRef]

56. Wheeler, H.C.; Danielsen, F.; Fidel, M.; Hausner, V.; Horstkotte, T.; Johnson, N.; Lee, O.; Mukherjee, N.; Amos, A.; Ashthorn, H.; et al. The need for transformative changes in the use of Indigenous knowledge along with science for environmental decision-making in the Arctic. People Nat. 2020, 2, 544-556. [CrossRef]

57. Wheeler, H.C.; Root-Bernstein, M. Informing decision-making with Indigenous and local knowledge and science. J. Appl. Ecol. 2020, 57, 1634-1643. [CrossRef]

58. Castro, A.P.; Nielsen, E. Indigenous people and co-management: Implications for conflict management. Environ. Sci. Policy 2001, 4, 229-239. [CrossRef]

59. Abdul-Rahaman, A.; Abdulai, A. Farmer groups, collective marketing and smallholder farm performance in rural Ghana. J. Agribus. Dev. Emerg. Econ. 2020, 10, 511-527. [CrossRef] 
60. Danielsen, F.; Burgess, N.D.; Jensen, P.; Pirhofer-Walzl, K. Environmental monitoring: The scale and speed of implementation varies according to the degree of peoples involvement. J. Appl. Ecol. 2010, 47, 1166-1168. [CrossRef]

61. Wall, T.U.; McNie, E.; Garfin, G.M. Use-inspired science: Making science usable by and useful to decision makers. Front. Ecol. Environ. 2017, 15, 551-559. [CrossRef] 